\title{
PEMBERDAYAAN ORANGTUA MELALUI PENDIDIKAN KESEHATAN REPRODUKSI UNTUK MENCEGAH SEKSUAL PRANIKAH PADA REMAJA
}

DOI: https://doi.org/10.33024/jkpm.v4i5.4330

\author{
Yuliana Dafroyati ${ }^{1}$, Ririn Widyastuti ${ }^{2 *}$ \\ ${ }^{1}$ Program Studi Keperawatan, Poltekkes Kemenkes Kupang \\ ${ }^{2}$ Program Studi Kebidanan, Poltekkes Kemenkes Kupang \\ Disubmit: 05 Mei 2021 Diterima: 28 Mei 2021 Diterbitkan: 03 Oktober 2021 \\ Email Korespondensi: ririenwidyastuti@gmail.com
}

\begin{abstract}
ABSTRAK
Kompleknya permasalahan kesehatan pada remaja memerlukan penanganan yang komprehensif dan terintegrasi. Dampak dari permasalahan remaja adalah terjadinya masalah pada kesehatan reproduksi remaja. Salah satu upaya untuk mencegah perilaku seksual pada remaja adalah optimalisasi peran orang tua khususnya Ibu, selama ini pemberdayaan belum dioptimalkan pada aspek ini sehingga penanganan terhadap risiko yang ditimbulkan oleh perilaku seksual pranikah pada remaja belum mendapat perhatian khusus. Tujuan pengabdian masyarakat adalah untuk mengoptimalkan peran orangtua dengan memberdayakan orangtua melalui pendidikan kesehatan reproduksi untuk mencegah seksual pranikah pada remaja Di KUB St. Yakobus Rasul Naimata Kupang. Pelaksanaan kegiatan pengabdian masyarakat dengan cara memberikan penyuluhan, konseling informasi dan edukasi (KIE) kepada orangtua di wilayah KUB St. Yakobus Rasul Naimata Kupang. Analisis univariate yaitu data yang diperoleh dari hasil pengumpulan data disajikan dalam bentuk tabel distribusi frekuensi. Analissis bivariate dengan menggunakan uji paired sample $t$ - test untuk mengetahui perbedaan sebelum dan setelah pemberian penyuluhan dan KIE pada orangtua remaja. Peningkatan rerata pengetahuan orangtua remaja sebelum perlakuan 64.90 dan setelah perlakuan meningkat menjadi 81.00. Hasil uji paired samples $t$-test menunjukkan bahwa ada perbedaan bermakna pengetahuan orangtua untuk mencegah seksual pranikah pada remaja di KUB St. Yakobus Rasul Naimata Kupang efektif untuk meningkatkan pengetahuan orangtua remaja $(p<0,05)$.
\end{abstract}

Kata Kunci : Pemberdayaan, Orangtua, Remaja, Seksual Pranikah

\begin{abstract}
The complexities of health problems in adolescents require comprehensive and integrated handling. The impact of adolescent problems is the occurrence of problems on adolescent reproductive health. One of the efforts to prevent sexual behavior in adolescents is to optimize the role of parents, especially mothers, so far empowerment has not been optimized in this aspect so that the handling of the risks posed by premarital sexual behavior in adolescents has not received special attention. The aim of community service is to optimize the role of parents by empowering parents through reproductive health education to prevent premarital sex among adolescents. Yakobus Apostle Naimata Kupang.
\end{abstract}


Implementation of community service activities by giving counseling, information counseling and education (KIE) to parents in the KUB St. Yakobus Apostle Naimata Kupang. Univariate analysis, namely data obtained from the results of data collection presented in the form of a frequency distribution table. Bivariate analysis using paired sample t-test to determine the differences before and after giving counseling and IEC to adolescent parents. The increase in the mean knowledge of the adolescent parents before treatment 64.90 and after treatment increased to 81.00. The results of the paired samples t-test showed that there were significant differences in parental knowledge to prevent premarital sex among adolescents in KUB St. Yakobus Rasul Naimata Kupang was effective in increasing the knowledge of teenagers' parents $(p<0.05)$.

Keywords: Empowerment, Parents, Adolescents, Premarital Sexuals

\section{PENDAHULUAN}

Masa remaja merupakan masa storm and stress, karena remaja mengalami banyak tantangan baik dari diri mereka sendiri (biopsychosocial factors) ataupun lingkungan (environmental factors). Apabila remaja tidak memiliki kemampuan untuk menghadapi berbagai tantangan tersebut, mereka dapat berakhir pada berbagai masalah kesehatan yang begitu kompleks sebagai akibat dari perilaku berisiko yang mereka lakukan (Sulastri, Astuti, \& Handyani, 2019). Menurut World Health Organization (WHO), Batasan usia remaja adalah usia 10-19 tahun. Secara demografis kelompok remaja dibagi menjadi kelompok usia 10 - 14 tahun dan kelompok usia 15 - 19 tahun. Undang-Undang No 23 tahun 2002 tentang Perlindungan Anak mengelompokkan setiap orang yang berusia sampai dengan 18 tahun sebagai anak, sehingga berdasarkan Undang-Undang ini sebagian besar remaja termasuk dalam kelompok anak (Kemenkes RI, 2015). Proporsi jumlah remaja umur 10 - 19 tahun pada tahun 2018 adalah 17.1 persen dari total jumlah penduduk atau sekitar 45 juta jiwa (BPS, 2019). Jumlah generasi milenial yang cukup besar tersebut merupakan potensi yang memerlukan pengelolaan secara terencana, terstruktur dan sistematis agar dapat bermanfaat menjadi modal pembangunan ke depan (Antara, 2017).

Remaja menghadapi berbagai masalah dan tantangan. Data Riskesdas 2018, menunjukkan bahwa sebanyak 0.3 persen remaja umur 10 - 14 tahun dan 3.7 persen remaja umur 15 - 19 tahun saat ini mengkonsumsi minuman beralkohol. Proporsi umur pertama kali merokok adalah 42.8 persen remaja umur 10 -14 tahun dan 54.2 persen remaja umur 15 - 19 tahun. 64.8 persen remaja belum mengetahui tentang HIV/AIDS (Badan Penelitian dan Pengembangan Kesehatan, 2019). Presentasi usia kawin pertama pada perempuan usia 15 - 19 tahun adalah 10.5 persen dan pada pria adalah 5.0 persen. 7 persen wanita umur 15 - 19 tahun sudah menjadi ibu. 5 persen sudah pernah melahirkan dan 2 persen sedang hamil anak pertama (BKKBN, BPS, \& Kemenkes RI, 2018).

Kompleknya permasalahan kesehatan pada remaja memerlukan penanganan yang komprehensif dan terintegrasi. Salah satu upaya untuk mencegah perilaku seksual pada remaja adalah optimalisasi peran orang tua khususnya Ibu, selama ini pemberdayaan belum dioptimalkan pada aspek ini sehingga penanganan terhadap risiko yang ditimbulkan oleh perilaku seksual pranikah pada remaja belum mendapat perhatian khusus. Berdasarkan konsep penanganan kesehatan, bahwa terabaikannya permasalahan 
disebabkan oleh ketidaktahuan, ketidakmampuan dan ketidakmauan. Berdasarkan uraian latar belakang diatas penulis tertarik untuk melakukan pengabdian masyarakat dengan judul "Pemberdayaan Orangtua Melalui Pendidikan Kesehatan Reproduksi Untuk Mencegah Seksual Pranikah Pada Remaja Di KUB St. Yakobus Rasul Naimata Kupang."

\section{MASALAH}

Alasan kami memilih KUB St. Yokabus Rasul Naimata Kupang berada di wilayah kota Kupang sehingga akses lebih mudah serta jarak lokasi peneliti dengan mitra adalah $4 \mathrm{~km}$ dengan waktu tempuh 10 menit. Jumlah ibu (orangtua) yang memiliki putra putri usia 10 - 19 tahun adalah 50 ibu. Jumlah remaja usia 10 - 19 tahun adalah 100 remaja. Alasan yang lain adalah Ketua Tim Pengusul merupakan fasilitator Pelayanan Kesehatan Peduli Remaja (PKPR) tingkat Provinsi NTT.

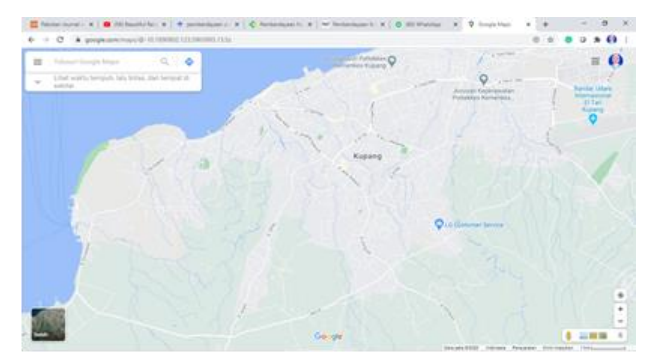

Gambar 2.1 Peta Lokasi Kegiatan Pengbdian Kepada Masyarakat.

\section{METODE}

\section{a. Tujuan Persiapan}

Kegiatan yang akan dilakukan pada tahap persiapan adalah persipan lokasi dan tim pelaksana

1. Persiapan dan Pembentukan tim kegiatan pengabdian masyarakat yang terdiri dari dosen dan mahasiswa Poltekkes Kemenkes Kupang serta tim KUB St. Yakobus Rasul Naimata dengan pembagian tugas sebagai berikut:

Tabel 3.1 Persiapan Pengabdian Masyarakat

\begin{tabular}{|c|c|}
\hline Sasaran & Peran \\
\hline $\begin{array}{l}\text { Fasilitator (Tim } \\
\text { Pengabdian Masyarakat) }\end{array}$ & $\begin{array}{l}\text { Mengorganisir dan memfasilitasi } \\
\text { kegiatan }\end{array}$ \\
\hline $\begin{array}{l}\text { Ketua KUB St. Yakobus } \\
\text { Naimata }\end{array}$ & $\begin{array}{l}\text { - Koordinasi dengan Tim Poltekkes } \\
\text { Kemenkes Kupang } \\
\text { - Bertanggungjawab atas pelaksanaan } \\
\text { kegiatan pengabdian masyarakat } \\
\text { - Menyiapkan tempat dan sarana } \\
\text { prasana untuk menunjang kegiatan } \\
\text { penyuluhan dan KIE }\end{array}$ \\
\hline Orangtua Remaja (Ibu) & Mendapatkan penyuluhan dan KIE \\
\hline
\end{tabular}

2. Menyiapkan alat bahan yang diperlukan untuk pelaksanaan kegiatan pengabdian masyarakat termasuk persiapan format kuisioner pre dan post serta evaluasi kegiatan pengabdian masyarakat. 
b. Tahap pelaksanaan

Pelaksanaan kegiatan digambarkan dalam skema dibawah ini:

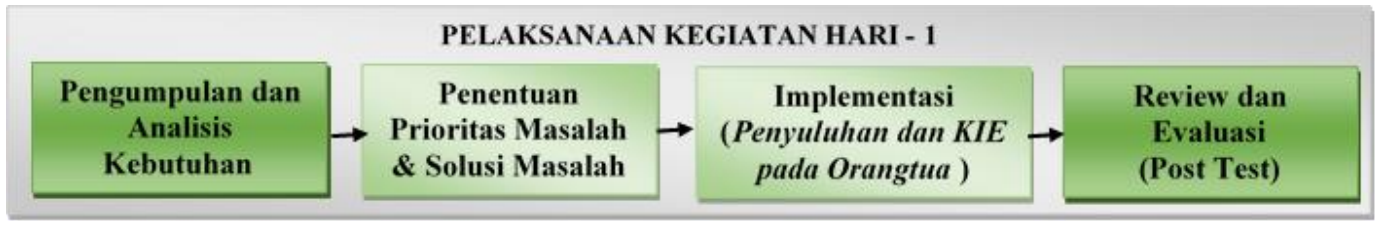

Gambar 3.1 Pelaksanaan Kegiatan Pengabdian Masyarakat

\section{Keterangan}

Kegiatan pengabdian kepada masyarakat unuk meningkatkan Kegiatan pengabdian kepada masyarakat unuk mengoptimalkan peran orangtua dengan memberdayakan orangtua melalui pemberian pendidikan kesehatan reproduksi untuk mencegah seksual pranikah pada remaja di KUB St. Yakobus Rasul Naimata Kupang, dengan rincian kegiatan sebagai berikut:

a. Pengumpulan dan Analisis Kebutuhan

Pengumpulan dan analisis kebutuhan dengan memberikan 20 pertanyaan pre test tentang perkembangan kesehatan reproduksi pada remaja, permasalahan pada remaja serta upaya untuk mencegah perilaku seksual pranikah pada remaja.

b. Penentuan Prioritas Masalah dan Solusi Kegiatan

Hasil pre test digunakan untuk menentukan prioritas dan solusi untuk memberikan penyuluhan dan KIE pada orangtua remaja.

c. Implementasi

Implementasi kegiatan dalam bentuk penyuluhan dan KIE pada orangtua remaja dengan materi penyuluhan dan KIE adalah Permasalahan pada kesehatan reproduksi remaja, dan upaya untuk mencegah perilaku seksual pranikah pada remaja.

d. Review dan evaluasi pengabdian masyarakat

Review dan evaluasi dengan memberikan post test pada orangtua remaja.

\section{c. Analisa Data}

Analisa data dengan menggunakan analisis univariate dan bivariate. Analisis univariate yaitu data yang diperoleh dari hasil pengumpulan data disajikan dalam bentuk tabel distribusi frekuensi. Analissis bivariate dengan menggunakan $u j i$ paired sample $t$ - test untuk mengetahui perbedaan sebelum dan setelah pemberian penyuluhan dan KIE pada orangtua remaja. 


\section{HASIL DAN PEMBAHASAN}

a. Hasil Pengabdian Masyarakat

Tabel 4.1 Distribusi Frekuensi Peningkatan Pengetahuan Orangtua Untuk Mencegah Seksual Pranikah Pada Remaja Di KUB St. Yakobus Rasul Naimata Kupang.

\begin{tabular}{|c|c|c|c|c|c|c|}
\hline \multirow[t]{2}{*}{ Pengetahuan } & \multicolumn{2}{|c|}{ Pre Test } & \multicolumn{2}{|c|}{ Post Test } & \multirow{2}{*}{$\begin{array}{l}\text { Standar } \\
\text { Deviasi }\end{array}$} & \multirow{2}{*}{$\begin{array}{c}p- \\
\text { Value }\end{array}$} \\
\hline & $\Sigma$ & $\%$ & $\Sigma$ & $\%$ & & \\
\hline Baik & 5 & 10 & 42 & 84.0 & 0.418 & 0,0001 \\
\hline Cukup & 40 & 80 & 5 & 10 & & \\
\hline Kurang & 5 & 10 & 3 & 6.0 & & \\
\hline Total & 50 & 100,0 & 60 & 100,0 & & \\
\hline
\end{tabular}

Tabel 4.2 Rerata Perubahan Pengetahuan Sebelum dan Setelah Pendidikan Kesehatan Reproduksi Untuk Mencegah Seksual Pranikah Pada Remaja Di KUB St. Yakobus Rasul Naimata Kupang

\begin{tabular}{|lc|r|r|}
\hline & & $\begin{array}{c}\text { Sebelum } \\
\text { Intervensi }\end{array}$ & $\begin{array}{c}\text { Setelah } \\
\text { Intervensi }\end{array}$ \\
\hline N $\quad$ Valid & 50 & 50 \\
& Missing & 0 & 0 \\
Mean & 64.90 & 81.00 \\
\hline
\end{tabular}

Berdasarkan grafik 4.1 menunjukkan bahwa terdapat peningkatan pengetahuan orangtua untuk mencegah perilaku seksual pranikah pada Remaja di KUB St. Yakobus Rasul Naimata Kupang. Pengetahuan orangtua sebelum diberikan pendidikan kesehatan tentang perkembangan kesehatan reproduksi pada remaja dan upaya untuk mencegah perilaku seksual pranikah pada Remaja di KUB St. Yakobus Rasul Naimata Kupang adalah baik 5 orang (10\%), Cukup 40 orang $(80 \%)$ dan kurang 5 orang $(10 \%)$. Pengetahuan orangtua setelah diberikan perlakuan baik 42 orang (84\%), cukup 5 orang (10\%) dan kurang 3 orang $(6 \%)$. Terdapat peningkatan pengetahuan orangtua setelah diberikan perlakuan. Pada tabel 4.2 menunjukkan peningkatan rerata pengetahuan orangtua yaitu sebelum perlakuan 64.90 dan setelah perlakuan meningkat menjadi 81.00. Hasil uji paired samples $t$-test menunjukkan bahwa ada perbedaan bermakna pengetahuan orangtua tentang perkembangan kesehatan reproduksi pada remaja dan upaya untuk mencegah perilaku seksual pranikah pada Remaja di KUB St. Yakobus Rasul Naimata Kupang $(p<0,05)$. Hasil pengabdian masyarakat ini menunjukkan bahwa intervensi pemberdayaan orangtua melalui pendidikan kesehatan reproduksi untuk mencegah seksual pranikah pada remaja di KUB St. Yakobus Rasul Naimata Kupang efektif untuk meningkatkan pengetahuan orangtua. Hal ini dapat dilihat dari peningkatan pengetahuan orangtua sebelum dan setelah dilakukan intervensi. Hal ini sesuai dengan penelitian yang dilakukan oleh Winarti \& Alamsyah, (2020) yaitu peran orang tua dalam mencegah perilaku seks pranikah memiliki posisi yang sangat penting. Penelitian ini bertujuan untuk menganalisis hubungan peran orang tua dengan perilaku inisiasi seks pranikah pada remaja di prodi S1 Farmasi Universitas Muhammadiyah Kalimantan Timur dengan p-value < 0.001. Salah satu faktor yang menentukan yaitu faktor penguat termasuk diantaranya peran orang tua. Peran orang tua merupakan salah satu alasan pokok yang menyebabkan remaja memiliki perilaku seks pranikah berat, sedang, dan ringan. Dalam hal berperilaku, dapat dijelaskan bahwa responden di SMK N 1 
Bantul yang memiliki peran orang tua baik cenderung berperilaku seks pranikah ringan, peran orang tua kurang baik remaja berperilaku seks pranikah sedang dan yang memiliki peran orang tua tidak baik cenderung berperilaku seks pranikah berat (Hidayat \& Nurhayati, 2020). Salah satu peran orangtua adalah melalui komunikasi orangtua dengan remaja. Komunikasi orang tua-remaja dalam hal seksualitas dapat menjelaskan perilaku seksual remaja (Widyarini, Retnowati, \& Setiyawati, 2019). Komunikasi tentang kesehatan reproduksi yang dilakukan oleh orang tua kepada anak akan membawa pengaruh terhadap prilaku seksual anak (Nurhidayah, 2011).

\section{KESIMPULAN}

a. Terdapat peningkatan rerata pengetahuan orangtua remaja sebelum dan setelah perlakuan/intervensi.

b.Intervensi pemberian pendidikan kesehatan reproduksi untuk mencegah seksual pranikah pada remaja di KUB St. Yakobus Rasul Naimata Kupang efektif untuk meningkatkan pengetahuan orangtua remaja.

\section{DAFTAR PUSTAKA}

Antara, A. (2017). Wow! Jumlah Remaja Indonesia 66,3 Juta Jiwa, Kekuatan atau Kelemahan? Okelifestyle. Retrieved from https: / / lifestyle.okezone.com/read/2017/10/25/196/1802143/wowjumlah-remaja-indonesia-66-3-juta-jiwa-kekuatan-atau-kelemahan

Badan Penelitian dan Pengembangan Kesehatan. (2019). National Riskesdas Report 2018. Basic Health Research 2018 (Laporan Nasional Riskesdas 2018). Riset Kesehatan Dasar 2018. Jakarta: Lembaga Penerbit Badan Penelitian dan Pengembangan Kesehatan.

BKKBN, BPS, \& Kemenkes RI. (2018). Survei Demografi Kesehatan Indonesia. USAID. Jakarta: USAID.

BPS. (2019). Statistik Indonesia 2019. (Subdirektorat Publikasi dan Kompilasi Statistik, Ed.), Badan Pusat Statistik. Jakarta: Badan Pusat Statistik.

Hidayat, A. R., \& Nurhayati, I. (2020). Peran Orang Tua Dalam Pencegahan Perilaku Sex Pranikah Pada Remaja Di Bantul. Jurnal Formil (Forum Ilmiah) Kesmas Respati, 71. https://doi.org/10.35842/formil.v5i1.304

Kemenkes RI. (2015). Petunjuk Teknis Penjaringan Kesehatan dan Pemeriksaan Berkala di Satuan Pendidikan Dasar dan Menengah. Jakarta.

Nurhidayah, Y. (2011). Pengaruh Komunikasi Orangtua Tentang Pengetahuan Kesehatan Reproduksi Dan Penanaman Nilai-nilai Religiusitas Terhadap Perilaku Seksual Remaja. Holistik, 12.

Sulastri, E., Astuti, D. P., \& Handyani, E. W. (2019). Pembentukan Posyandu Remaja Desa Madureso Kecamatan Kuwarasan Kabupaten Kebumen. Urecol, 130-133.

Widyarini, N., Retnowati, S., \& Setiyawati, D. (2019). Peran Komunikasi dengan Orang Tua dan Perilaku Seksual Remaja: Studi Metaanalisis. Jurnal Ilmu Keluarga Dan Konsumen, 12(2), 126-144. https: //doi.org/10.24156/jikk.2019.12.2.126

Winarti, Y., \& Alamsyah, W. A. B. (2020). Hubungan Peran Orang Tua dengan Inisiasi Seks Pranikah pada Remaja di Prodi S1 Farmasi Universitas Muhammadiyah Kalimantan Timur. Jurnal Dunia Kesmas, 9(3). 